\title{
Article \\ Biphasic Properties of PVAH (Polyvinyl Alcohol Hydrogel) Reflecting Biomechanical Behavior of the Nucleus Pulposus of the Human Intervertebral Disc
}

\author{
Minhyeok Heo and Seonghun Park *(D) \\ School of Mechanical Engineering, Pusan National University, Busan 46241, Korea; hmh555@hanmail.net \\ * Correspondence: paks@pusan.ac.kr
}

check for

updates

Citation: Heo, M.; Park, S. Biphasic Properties of PVAH (Polyvinyl Alcohol Hydrogel) Reflecting Biomechanical Behavior of the Nucleus Pulposus of the Human Intervertebral Disc. Materials 2022, 15 1125. https://doi.org/10.3390/ ma15031125

Academic Editor: Guangkui Xu

Received: 28 December 2021

Accepted: 27 January 2022

Published: 31 January 2022

Publisher's Note: MDPI stays neutral with regard to jurisdictional claims in published maps and institutional affiliations.

Copyright: (C) 2022 by the authors. Licensee MDPI, Basel, Switzerland. This article is an open access article distributed under the terms and conditions of the Creative Commons Attribution (CC BY) license (https:// creativecommons.org/licenses/by/ $4.0 /)$.

\begin{abstract}
PVAH is a mixture of solid and fluid, but its mechanical behavior has usually been described using solid material models. The purpose of this study was to obtain material properties that can reflect the mechanical behavior of polyvinyl alcohol hydrogel (PVAH) using finite element analysis, a biphasic continuum model, and to optimize the composition ratio of PVAH to replace the nucleus pulposus (NP) of the human intervertebral disc. Six types of PVAH specimens $(3,5,7,10,15,20 \mathrm{wt} \%)$ were prepared, then unconfined compression experiments were performed to acquire their material properties using the Holmes-Mow biphasic model. With an increasing weight percentage of PVA in PVAH, the Young's modulus increased while the permeability parameter decreased. The Young's modulus and permeability parameter were similar to those of the NP at $15 \mathrm{wt} \%$ and $20 \mathrm{wt} \%$. The range of motion, facet joint force, and NP pressures measured from dynamic motional analysis of the lumbar segments with the NP model also exhibited similar values to those with 15 20 wt $\%$ PVAH models. Considering the structural stability and pain of the lumbar segments, it appears that $20 \mathrm{wt} \%$ PVAH is most suitable for replacing the NP.
\end{abstract}

Keywords: PVAH; lumbar spine; biphasic continuum model; nucleus pulposus; Holmes-Mow model

\section{Introduction}

Low back pain is the most common disease in modern society. Degenerative intervertebral discs (IVDs) account for more than $75 \%$ of the causes of low back pain [1]. The nucleus pulposus (NP) of the IVD applies intradiscal pressure to the annulus fibrosus (AF) [2]. When the NP of the degenerated IVD has reduced water content, there is abnormal stress on the AF [2-4]; this condition is treated by using a replacement for the NP [5]. NP replacement can reduce pain while restoring spine mobility and delay IVD degeneration [6-11]. Moreover, this treatment has the advantage of preserving AF with minimally invasive surgery.

Some studies have reported that the NP can be modeled as an incompressible fluid and an isotropic solid with a porous structure [4,12-16], while others have shown that the NP exhibits properties of both solid and fluid materials simultaneously $[4,17,18]$. Although various studies have been conducted to explore the material models of the NP by performing experimental and analytical studies $[14,19,20]$, these material models do not accurately reflect the biomechanical behavior of the NP and that of the entire IVD with the NP [21]. Currently, a biphasic continuum model that implements anisotropy, nonlinearity, and inhomogeneity is widely used to model the NP and simulate its biomechanical behavior [22-25].

Hydrogels are crosslinked polymer networks with high water content. Polyvinyl alcohol (PVA) is a synthetic water-soluble polymer with low toxicity, excellent mechanical strength, and high biocompatibility. PVA hydrogel (PVAH) has been used in various applications, including arterial phantoms [26], heart valves [27], corneal implants [28], and artificial cartilage [29]. PVAH exhibits a large deformation for relatively small mechanical 
loads and time-dependent viscoelastic behavior, such as rubber materials. One of the applications of this material is the treatment of degenerative IVDs [30,31]. To investigate the mechanical behavior of PVAH, various tests, including unconfined and confined compression tests, have been performed, and PVAH has been described using hyperelastic and viscoelastic material models $[1,32,33]$. However, because PVAH consists of a porous solid (PVA) and a fluid (body fluid) that fills it, there are limitations in describing its mechanical behavior with material models that only simulate its solid part.

Therefore, the purpose of this study was to obtain the material properties of PVAH, and then optimize its composition ratio such that it can reflect the mechanical behavior of the NP, using finite element analysis (FEA) and a biphasic continuum model. To this end, PVAH specimens with various composition ratios of PVA and PBS were first generated to experimentally measure the material properties used for the NP in the finite element (FE) model of the lumbar spine. Next, in the lumbar spine model with PVAH to replace the NP, the range of motion (ROM) and facet joint force (FJF) for flexion, extension, lateral bending, and axial torsion were analyzed to select the optimal PVAH composition ratio.

\section{Materials and Methods}

\subsection{PVAH Specimen Preparation}

In Jordan's unconfined test results, the maximum compressive stress of human nucleus pulposus was about $4 \mathrm{kPa}$ [33], and this value was less than the maximum compressive stress of 10\% PVA in Kobayasi's study [34]. Therefore, in this study, PVAH having a composition between $3 \mathrm{wt} \%$ and $20 \mathrm{wt} \%$, polyvinyl alcohol was selected as follows:

Phosphate-buffered saline (PBS, $\times 10$ Concentrate, Sigma-Aldrich, St. Louis, MO, USA) was diluted ten times with distilled water. PVA (polyvinyl alcohol, molecular weight $\sim 89,000-98,000 \mathrm{~g} / \mathrm{mol}, 99+\%$ hydrolyzed, Sigma-Aldrich, St. Louis, MO, USA) with a molecular weight $(\mathrm{Mw})$ of $8.9 \times 10^{4} \sim 9.8 \times 10^{4}$ was prepared. Six types of PVAH specimens (PVAH1: $3 \mathrm{wt} \%$ PVA and $97 \mathrm{wt} \%$ PBS; PVAH2: $5 \mathrm{wt} \%$ PVA and $95 \mathrm{wt} \%$ PBS; PVAH3: 7 $w t \%$ PVA and $93 \mathrm{wt} \%$ PBS; PVAH4: 10wt $\%$ PVA, $90 \mathrm{wt} \%$ PBS; PVAH5: $15 \mathrm{wt} \%$ PVA, 85 wt $\%$ PBS; PVAH6: $20 \mathrm{wt} \%$ PVA, $80 \mathrm{wt} \%$ PBS) were prepared.

When preparing the specimen, the PVA:PBS solution was stirred and heated for $2 \mathrm{~h}$. The temperature was gradually raised to $160{ }^{\circ} \mathrm{C}$ by stirring the specimen at a speed of $120 \mathrm{rpm}$ for $1 \mathrm{~h}$ and $30 \mathrm{~min}$. The temperature was then increased slowly to $220{ }^{\circ} \mathrm{C}$ for $30 \mathrm{~min}$ by stirring at $60 \mathrm{rpm}$ to prevent excessive evaporation due to a sudden phase change. Finally, to remove bubbles generated during stirring and heating, the temperature was reduced to $100{ }^{\circ} \mathrm{C}$, and the heating conditions were maintained for approximately $10 \mathrm{~min}$, after which the stirring was stopped. The prepared PVAH specimen was poured into a self-made mold and stored at room temperature for $10 \mathrm{~h}$ for bubble removal and stabilization. The samples were then frozen at $-20^{\circ} \mathrm{C}$ for $10 \mathrm{~h}$ and thawed at $3{ }^{\circ} \mathrm{C}$ for $20 \mathrm{~h}$. This process was repeated five times [35]. The completed PVAH specimen was placed in a $1 \times$ PBS solution and stored in a refrigerator (Figure 1). 


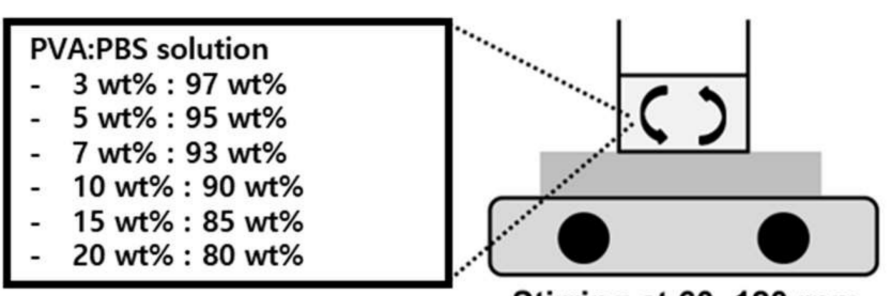

Stirring at $60,120 \mathrm{rpm}$

Heating at $90,110,220^{\circ} \mathrm{C}$

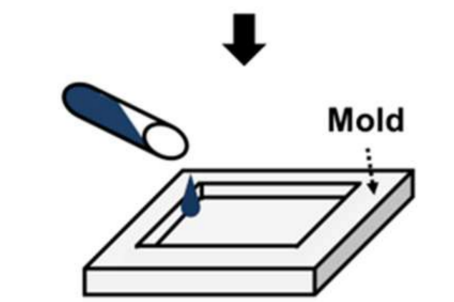

Cooling at room temperature

in the mold for $10 \mathrm{~h}$

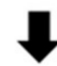

Freezing-thawing of 5 cycles

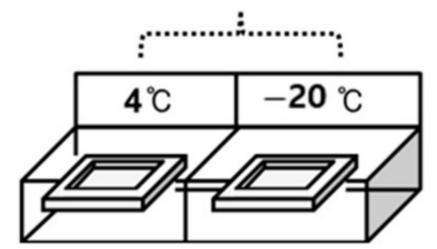

Freezing at $-20^{\circ} \mathrm{C}$ for $10 \mathrm{~h}$

Thawing at $4{ }^{\circ} \mathrm{C}$ for $20 \mathrm{~h}$

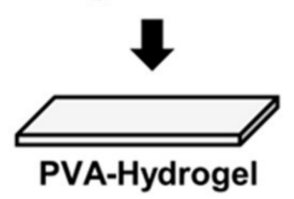

Figure 1. Schematic diagram of PVAH (Polyvinyl Alcohol Hydrogel) production process.

\subsection{Holmes-Mow Model}

The Holmes-Mow material model was used to represent the non-fibrillar solid matrix of soft tissues, including articular cartilage and annulus fibrosus [20,36-39]. The HolmesMow model is expressed in terms of elastic solids and hydraulic permeability.

Here, elastic solids can be formulated constitutively by the coupled hyperelastic strain-energy function ( $\Psi)$, as described by

$$
\Psi\left(I_{1}, I_{2}, J\right)=\frac{1}{2} c\left(e^{Q}-1\right)
$$

where $I_{1}$ and $I_{2}$ are the first and second invariants of the right Cauchy-Green tensor, and $J$ is the Jacobian of the deformation. The exponential strain components related to function $Q$ and material parameter $c$ are formulated by:

$$
\begin{gathered}
Q=\frac{\beta}{\lambda+2 \mu}\left[(2 \mu-\lambda)\left(I_{2}-3\right)+\lambda\left(I_{2}-3\right)-(\lambda+2 \mu) \ln \left(J^{2}\right)\right] \\
c=\frac{\lambda+2 \mu}{2 \beta}
\end{gathered}
$$


where $\beta$ is the exponential stiffening coefficient that accounts for the nonlinearity of the matrix stress-strain response. The material parameters $\lambda$ and $\mu$ can be expressed by Young's modulus $(E)$ and Poisson's ratio $(v)$ as follows:

$$
\begin{gathered}
\lambda=E /(1+v)(1-2 v) \\
\mu=E /(2(1+v))
\end{gathered}
$$

In biological tissues, compressive forces reduce the size and change the shape of the pores within a solid matrix. This leads to a nonlinear increase in the frictional interaction and momentum exchange between the fluid and solid. To explain this, Holmes-Mow's hydraulic permeability is employed as follows:

$$
k(J)=k_{0}\left(\frac{J-\varphi_{0}}{1-\varphi_{0}}\right)^{\alpha} e^{\frac{1}{2} M\left(J^{2}-1\right)}
$$

where $J$ is the Jacobian of the deformation, $k$ is the hydraulic permeability in the current state, $k_{0}$ is the permeability in the reference state, $\varphi_{0}$ is the solid volume fraction in the reference state, $M$ is the exponential strain-dependent coefficient, and $\alpha$ is the power law exponent.

\subsection{Unconfined Compression Experiments}

Unconfined compression experiments were performed using a dynamic material tester (Model 809, MTS Systems, Eden Prairie, MN, USA) with a $500 \mathrm{~N}$ load cell. A transparent acrylic chamber with a height of $10 \mathrm{~cm}$ was used to place the PVAH specimens with PBS solution (Figure 2). For the unconfined compression experiments, 30 PVAH specimens (five specimens $\times$ six types of PVAH: five specimens for each type of PVAH), $30 \mathrm{~mm}$ in diameter and $30 \mathrm{~mm}$ in height, were prepared and loaded with a flat indenter attached to the load cell. The indenter was initially lowered to contact the specimen. Compressive loads were then applied to the specimen up to $25 \%$ strain at a rate of $5 \%$ per minute. The $5 \%$ strain was maintained for $3 \mathrm{~h}$ to observe the stress relaxation.

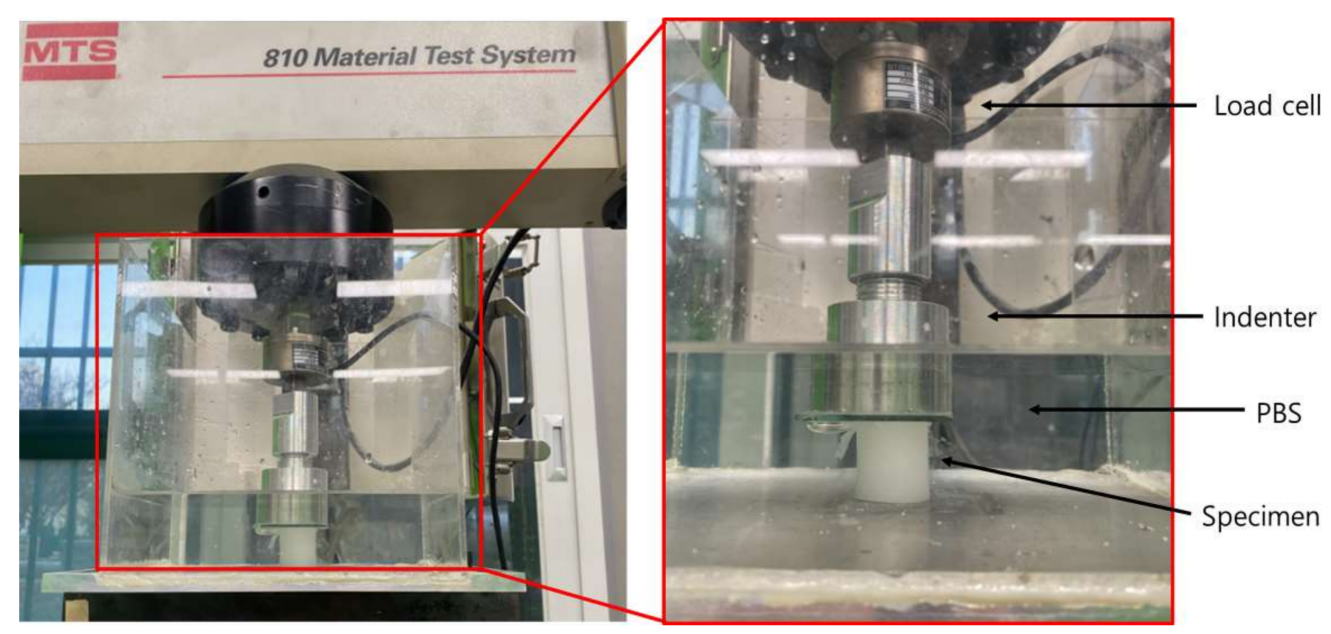

Figure 2. Material testing apparatus.

The experimental results were curve-fitted to the Holmes-Mow model using the optimization algorithm of FEBio software (open-source, version 1.5.0, Weiss Lab-University of Utah, and Ateshian Lab-Columbia University, USA), and the elastic parameters in the model, such as Young's modulus $(E)$, Poisson's ratio $(v)$, nonlinear permeability parameters $k_{0}$ and exponential coefficients $\beta$ and $M$, were extracted. 


\subsection{Range of Motion (ROM), Facet Joint Force (FJF), and Nucleus Pulposus (NP) Pressures}

The lumbar finite element (FE) model was generated using lumbar shape data from the Human Anatomy Model (Viewpoint Datalabs, Orem, Utah, USA). The lumbar vertebrae are composed of cancellous bone, cortical bone, posterior element, and endplate. The endplate was modeled as a bony endplate (BEP) and cartilage endplate (CEP). A linear elastic model was adopted for cancellous bone, cortical bone, the posterior element, and BEP, while the Holmes-Mow model was used for CEP. The articular cartilage of the facet joint was modeled to be attached to the upper and lower posterior elements, and the initial gap between the upper and lower cartilages was set to $0.5 \mathrm{~mm}$. It was assumed that there was no friction between the upper and lower cartilage of the facet joint $[40,41]$.

The intervertebral disc (IVD) was modeled with annulus fibrosis (AF) and nucleus pulposus (NP) [42,43]. The AF was modeled as two layers of the outer annulus fibrosus (OAF) and inner annulus fibrosus (IAF) [44]. The solid matrix of the AF was modeled using the Mooney-Rivlin model, whereas its fluid was modeled using the Holmes-Mow hydraulic permeability. The AF fiber was simulated by adding a fiber-pow-linear model to the Mooney-Rivlin model of the solid matrix. The fluid and solid of the NP were simulated using the Holmes-Mow model (Table 1).

Table 1. Material properties of lumbar spine components.

\begin{tabular}{|c|c|c|c|}
\hline Component & $\begin{array}{l}\text { Young's Modulus } \\
\text { (MPa) }\end{array}$ & Poisson Ratio & Reference \\
\hline Cortical bone & 12,000 & 0.3 & [45-47] \\
\hline Cancellous bone & 100 & 0.2 & [45-47] \\
\hline Posterior elements & 3500 & 0.25 & [45-47] \\
\hline Cartilage endplate & \multicolumn{2}{|c|}{$\begin{array}{c}\text { Holmes-Mow } \\
E=0.5218, v=0.38, \beta=0.0028 \\
k_{0}=5.5 \times 10^{-16}\left(\mathrm{~m}^{4} / \mathrm{Ns}\right), M=0.22\end{array}$} & [19] \\
\hline Bony endplate & 1000 & 0.3 & [19] \\
\hline Cartilage & 11 & 0.4 & {$[48]$} \\
\hline Nucleus pulposus & \multicolumn{2}{|c|}{$\begin{array}{c}\text { Holmes-Mow } \\
E=0.202, v=0.36, \beta=1.46 \\
k_{0}=18.7 \times 10^{-16}\left(\mathrm{~m}^{4} / \mathrm{Ns}\right), M=4.8\end{array}$} & [19] \\
\hline Inner anterior & \multicolumn{2}{|c|}{$\begin{array}{c}\text { Mooney-Rivlin } \\
C_{1}=0.2, C_{2}=0.01, k=6 \\
\text { Fiber-pow-linear } \\
E=12.5, \beta=5.5, \lambda_{0}=1.135\end{array}$} & [44] \\
\hline Outer anterior & \multicolumn{2}{|c|}{$\begin{array}{c}\text { Mooney-Rivlin } \\
C_{1}=0.2, C_{2}=0.01, k=6 \\
\text { Fiber-pow-linear } \\
E=46, \beta=4, \lambda_{0}=1.065\end{array}$} & [44] \\
\hline Ligament & \multicolumn{2}{|c|}{ Nonlinear stress-strain curve } & [49-51] \\
\hline
\end{tabular}

Lastly, the lumbar ligaments, including the anterior longitudinal ligament (ALL), posterior longitudinal ligament (PLL), transverse ligament (TL), interspinous ligament (ISL), supraspinous ligament (SSL), capsular ligament (CL), and ligamentum flavum (LF), were modeled to be attached to the lumbar spine based on anatomical information. The behavior of the ligament was simulated using a spring element that only resists tension (Figure 3) [49-51]. 

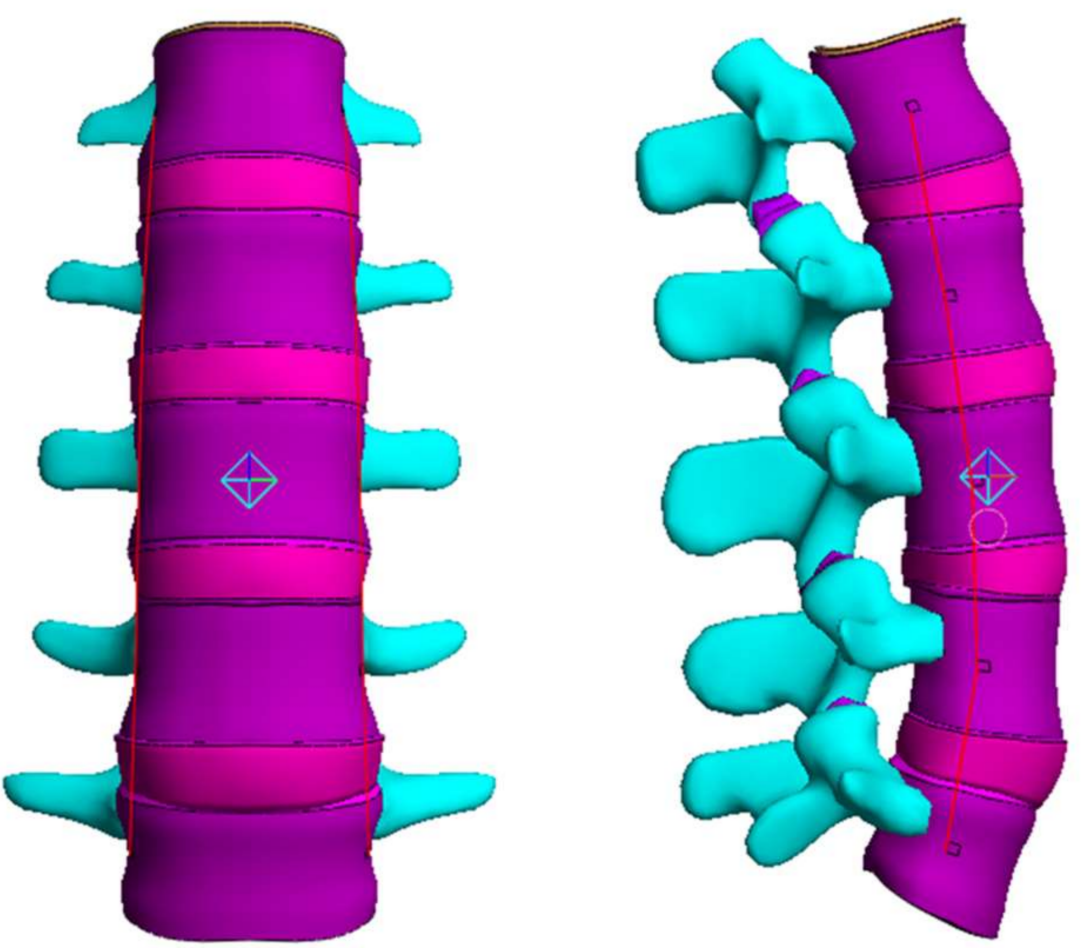

Figure 3. Finite element (FE) model of the lumbar segments.

To validate the normal lumbar FE model, the ROMs, FJFs, and NP pressures (maximum stresses of the IAF and OAF) were compared with analytical and experimental literature findings for flexion, extension, lateral bending, and axial torsion motions. To compare the literature findings and the current results, the loading conditions shown in Table 2 were applied to the upper surface of the L1 lumbar vertebrae, while the lower surface of the L5 lumbar vertebra was fixed so as not to cause displacement in any direction [52-54]. For finite element (FE) analysis of PVAH composition optimization, the ROM and FJF for flexion, extension, lateral bending, and axial torsion motions were calculated under the same loading conditions as above (Table 2). Here, the material properties of six different types of PVAH specimens were experimentally obtained from the unconfined compression experiments and subsequent curve fitting and then used in the Holmes-Mow model of the NP. The results of the ROMs and FJFs were compared with the analytical and experimental results of the normal lumbar FE model with the normal NP.

Table 2. Follower load and moment values of lumbar spine movements.

\begin{tabular}{cccc}
\hline & Follower Load (N) & Moment (N.m) & References \\
\hline Flexion & 1175 & 7.5 & {$[52]$} \\
\hline Extension & 500 & 7.5 & {$[52]$} \\
\hline Lateral bending & 700 & 7.8 & {$[53]$} \\
\hline Axial rotation & 720 & 5.5 & {$[54]$} \\
\hline
\end{tabular}

\section{Results}

\subsection{Unconfined Compression Experiments}

In the unconfined compression experiments, all six types of PVAH exhibited a nonlinear stress-strain response curve (Figure 4). The maximum compressive stress of $20 \mathrm{wt} \%$ PVAH was greater than those of $3 \mathrm{wt} \%$ PVAH by about 143 times. The stress-relaxation rate was about 4.27 times greater for $3 \mathrm{wt} \%$ PVAH compared to $20 \mathrm{wt} \%$ PVAH. As the water content of PVAH increased, the maximum compressive stress decreased, whereas the amount of stress relaxation behavior increased. The elastic and permeability parameters 
in the Holmes-Mow model to represent PVAH in FEA were acquired by curve fitting of these results using the optimization algorithm of FEBio (Figure 5). It was found that the Holmes-Mow model could successfully fit the experimental stress-strain response data with errors less than $1 \times 10^{-6}$. With an increasing PVA content of PVAH, the Young's modulus $(E)$ increased, while the nonlinear permeability parameter $\left(k_{0}\right)$ decreased (Table 3 ).
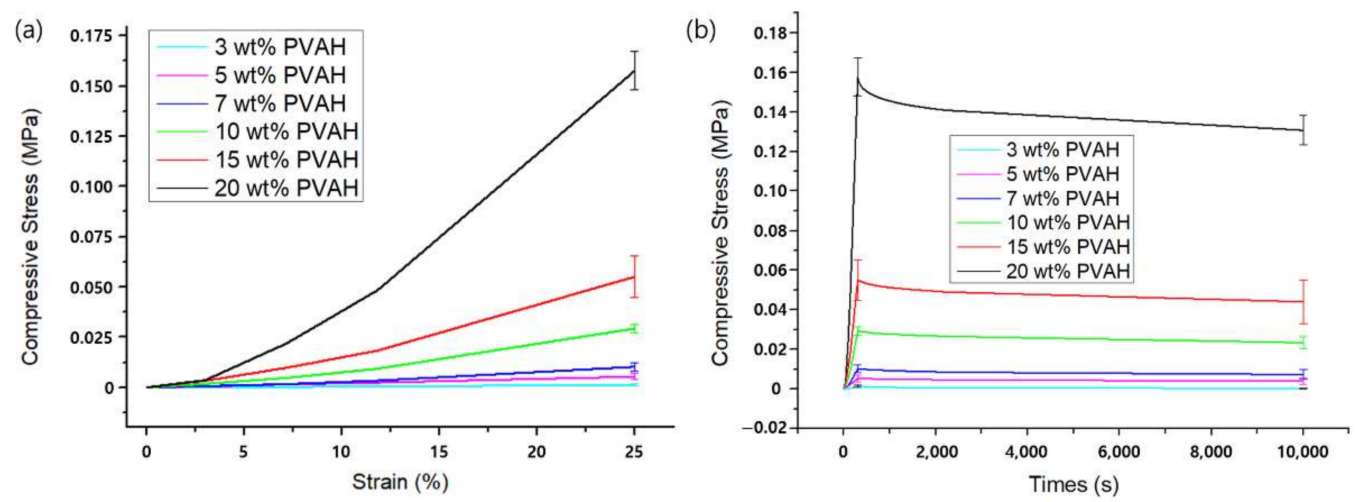

Figure 4. (a) Stress-strain and (b) stress-relaxation curves of six types of typical PVAH specimens with different composition ratios of PVA and PBS obtained from unconfined compression experiments.

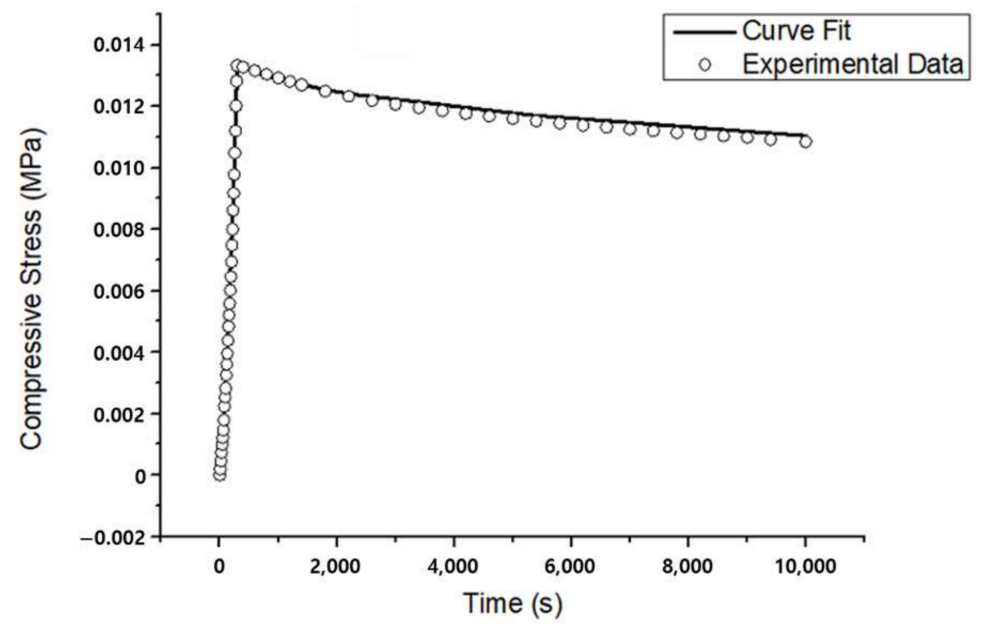

Figure 5. Stress relaxation curve as a function of time and corresponding curve fit $\left(R^{2}=0.999\right)$ for a typical PVAH specimen with $7 \mathrm{wt} \%$ PVA and $93 \mathrm{wt} \%$ PBS.

Table 3. Parameter values used in the Holmes-Mow model for PVAH.

\begin{tabular}{ccccccc}
\hline & $\mathbf{3} \mathbf{w t} \% \mathbf{( n = 5 )}$ & $\mathbf{5} \mathbf{w t} \mathbf{~ ( n = 5 )}$ & $\mathbf{7} \mathbf{w t} \% \mathbf{( n = 5 )}$ & $\mathbf{1 0} \mathbf{w t} \% \mathbf{( n = 5 )}$ & $\mathbf{1 5} \mathbf{w t} \% \mathbf{( n = 5 )}$ & $\mathbf{2 0} \mathbf{w t} \mathbf{~ ( n = 5 )}$ \\
\hline$E(\mathrm{kPa})$ & $2.2 \pm 0.5$ & $10.4 \pm 3.5$ & $21.0 \pm 4.6$ & $52.3 \pm 3.6$ & $123.3 \pm 21.5$ & $347.4 \pm 32.6$ \\
\hline$v$ & $0.15 \pm 0.5$ & $0.17 \pm 0.05$ & $0.22 \pm 0.01$ & $0.23 \pm 0.03$ & $0.29 \pm 0.03$ & $0.3 \pm 0.008$ \\
\hline$\beta$ & $1.32 \pm 0.38$ & $0.46 \pm 0.2$ & $0.74 \pm 0.16$ & $1.58 \pm 0.21$ & $0.46 \pm 0.20$ & $0.45 \pm 0.25$ \\
\hline $\begin{array}{c}k_{0} \times 10^{-16} \\
\left(\mathrm{~m}^{4} / \mathrm{N} \cdot \mathrm{s}\right)\end{array}$ & $23,262 \pm 4768$ & $2998 \pm 596$ & $357.3 \pm 110.7$ & $191.8 \pm 84.6$ & $73.8 \pm 16.9$ & $11.7 \pm 2.2$ \\
\hline$M$ & $1.6 \pm 0.5$ & $5.99 \pm 2.11$ & $4.47 \pm 2.19$ & $6.83 \pm 2.71$ & $8.30 \pm 2.25$ & $5.5 \pm 2.4$ \\
\hline $\begin{array}{c}R^{2} \\
(\text { Curve-fitting) }\end{array}$ & $0.928 \pm 0.032$ & $0.981 \pm 0.019$ & $0.997 \pm 0.004$ & $0.999 \pm 0.01$ & $0.999 \pm 0.000$ & $0.998 \pm 0.001$ \\
\hline
\end{tabular}


The $E$ and $k_{0}$ of the NP were between those of $15 \mathrm{wt} \% \mathrm{PVAH}$ and $20 \mathrm{wt} \% \mathrm{PVAH}$. The $E$ of the NP was $\sim 39 \%$ higher than that of $15 \mathrm{wt} \%$ PVAH and $\sim 72 \%$ lower than that of $20 \mathrm{wt} \%$ PVAH, while $k_{0}$ of the NP was $\sim 295 \%$ lower than that of $15 \mathrm{wt} \%$ PVAH and $\sim 37 \%$ higher than that of $20 \mathrm{wt} \%$ PVAH.

\subsection{Range of Motion (ROM), Facet Joint Force (FJF), and Nucleus Pulposus (NP) Pressures}

To verify the modeled lumbar spine segments, the ROM for flexion, extension, lateral bending, and axis torsion motions measured under a combination of moments and follower loads were compared with the results of previous studies. The present results were consistent with the ROMs measured in previous in vivo and analytical studies (Figure 6) [55-58]. Likewise, the FJFs and NP pressures for flexion, extension, lateral bending, and axis torsion motions were consistent with previous findings measured from lumbar spine finite element (FE) models (Figures 7 and 8) [55-58].
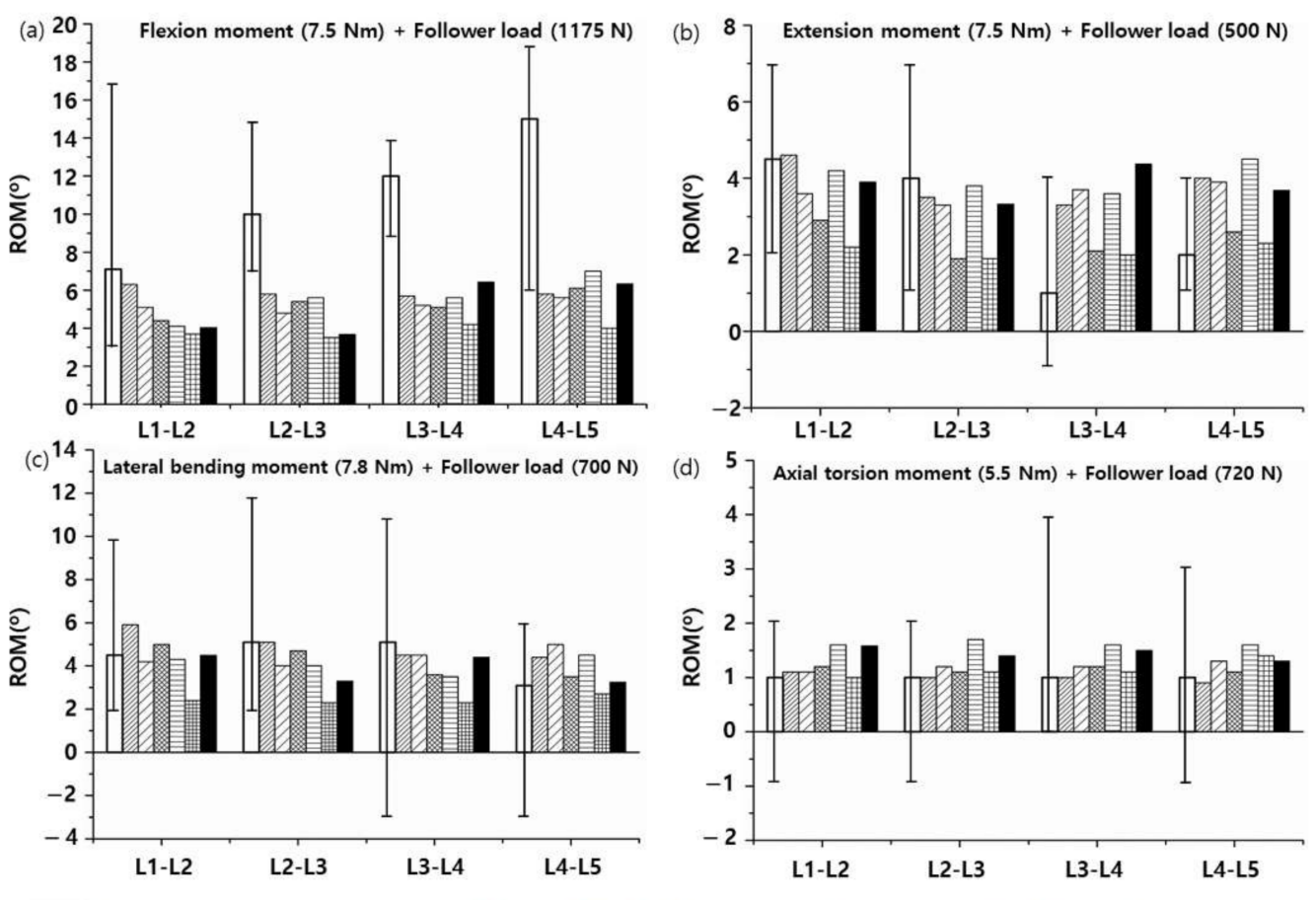

Pearcy and Tibrewal (In-vivo)

Kim and Park (FEM)

DPuttlitz and Labus (FEM)

Current Study

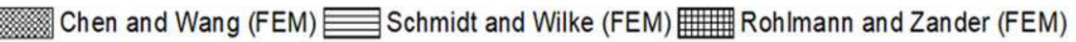

Figure 6. Range of motions (ROMs) of the healthy lumbar spine segments measured under a combination of (a) flexion moment $(7.5 \mathrm{~N} \cdot \mathrm{m})$ and follower load $(1175 \mathrm{~N}),(\mathbf{b})$ extension moment $(7.5 \mathrm{~N} \cdot \mathrm{m})$ and follower load $(500 \mathrm{~N}),(\mathrm{c})$ lateral bending moment $(7.8 \mathrm{~N} \cdot \mathrm{m})$ and follower load $(700 \mathrm{~N})$, and $(\mathrm{d})$ axial rotation moment $(5.5 \mathrm{~N} \cdot \mathrm{m})$ and follower load $(720 \mathrm{~N})$ (the white bars represent in vivo experimental results of the ROM for the L4-L5 segment, and other bars represent previous and current findings obtained from finite element analyses). 

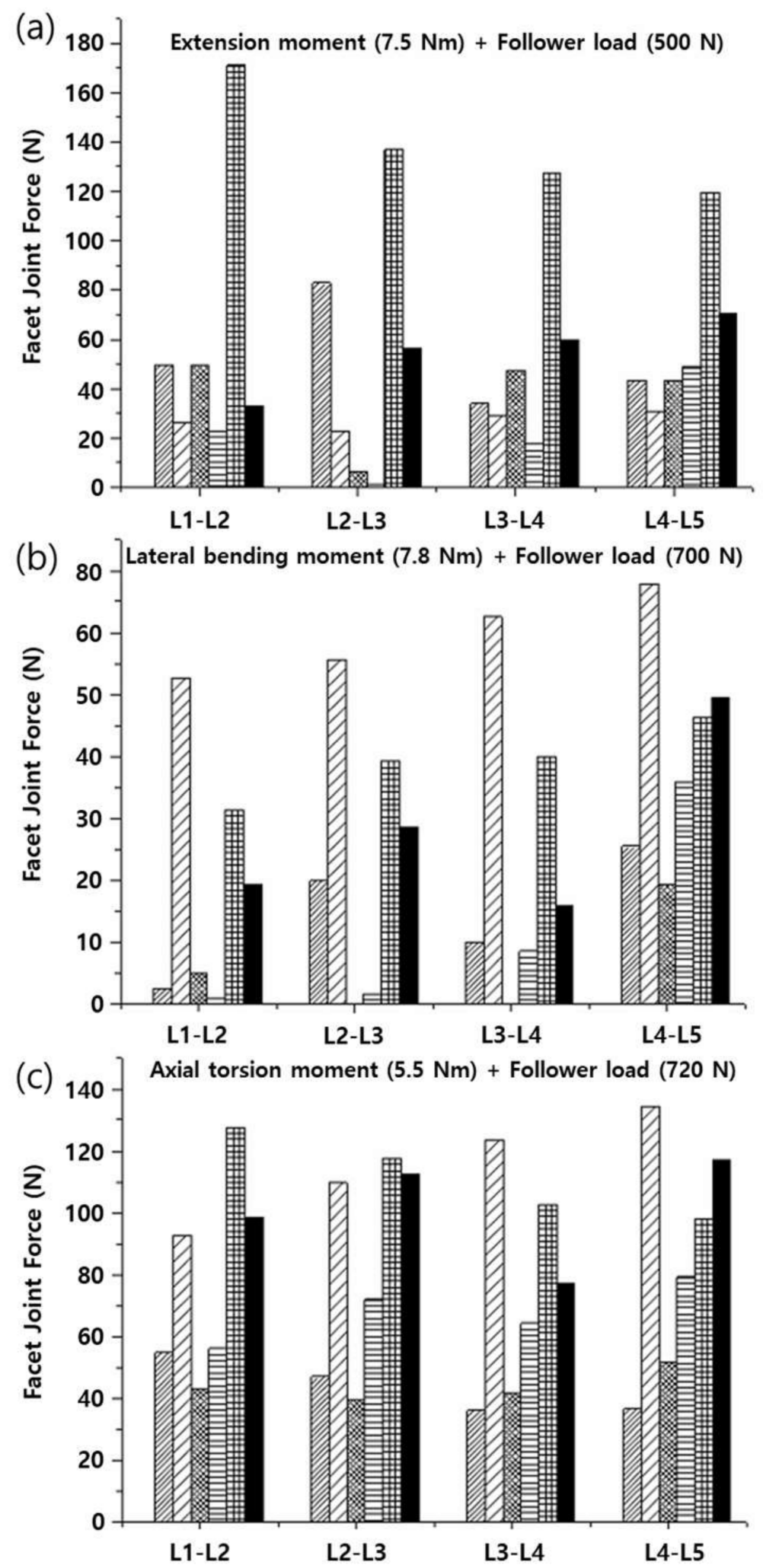

VIIIIS Kim and Park (FEM) VID Puttlitz and Labus (FEM) Chen and Wang (FEM) 四册 Rohlmann and Zander (FEM) Current Study

Figure 7. Facet joint forces (FJFs) of the healthy lumbar spine segments measured under a combination of (a) extension moment $(7.5 \mathrm{~N} \cdot \mathrm{m})$ and follower load $(500 \mathrm{~N})$, (b) lateral bending moment $(7.8 \mathrm{~N} \cdot \mathrm{m})$ and follower load $(700 \mathrm{~N})$, and (c) axial rotation moment $(5.5 \mathrm{~N} \cdot \mathrm{m})$ and follower load $(720 \mathrm{~N})$. 

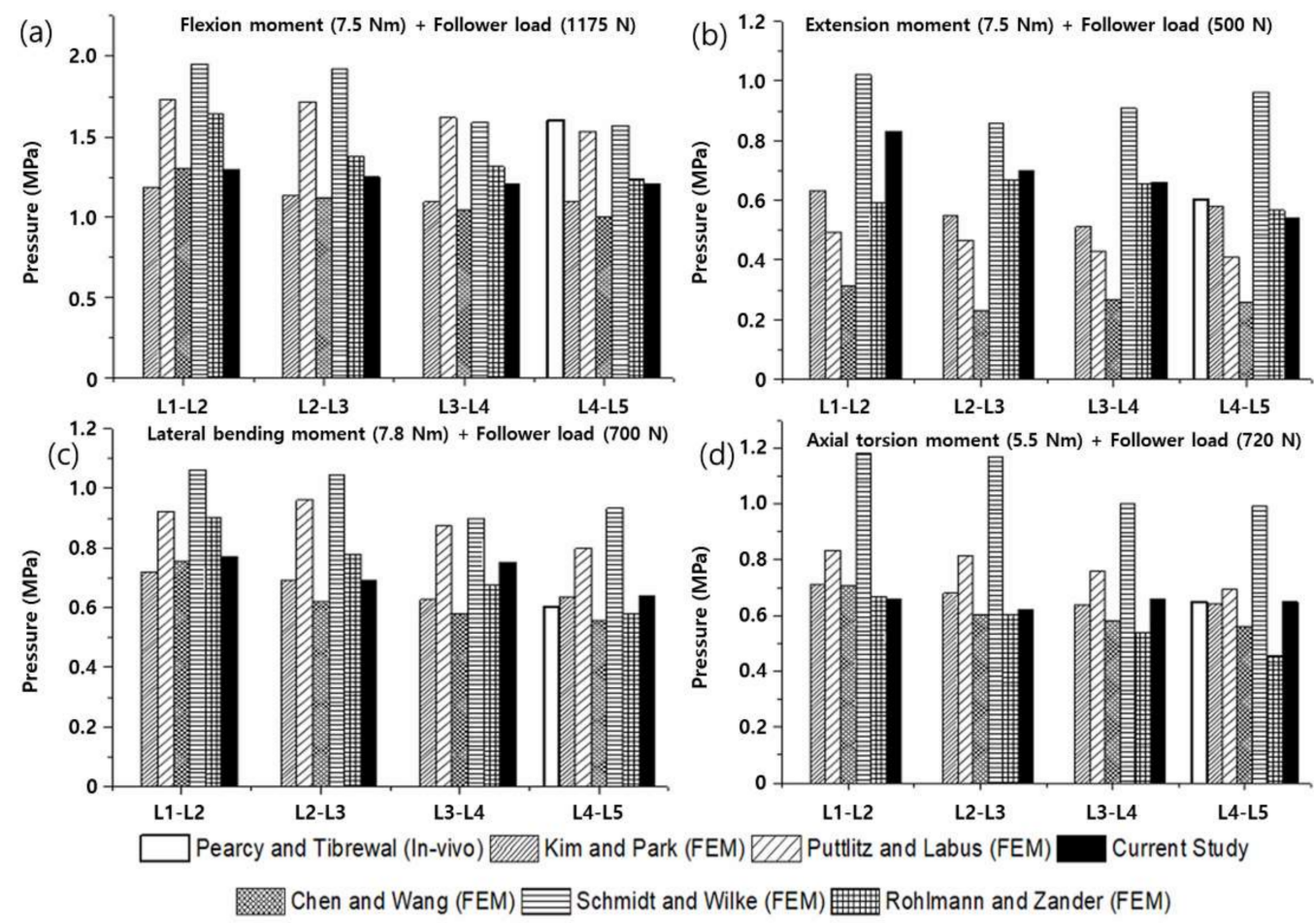

Figure 8. Nucleus pulposus (NP) pressures of the healthy lumbar spine segments measured under a combination of (a) flexion moment $(7.5 \mathrm{~N} \cdot \mathrm{m})$ and follower load $(1175 \mathrm{~N}),(\mathbf{b})$ extension moment $(7.5 \mathrm{~N} \cdot \mathrm{m})$ and follower load $(500 \mathrm{~N})$, (c) lateral bending moment $(7.8 \mathrm{~N} \cdot \mathrm{m})$ and follower load $(700 \mathrm{~N})$, and $(\mathrm{d})$ axial rotation moment $(5.5 \mathrm{~N} \cdot \mathrm{m})$ and follower load $(720 \mathrm{~N})$ (the white bars represent in vivo experimental results of the NP pressures for the L4-L5 segment, and other bars represent previous and current findings obtained from finite element analyses).

The ROM and FJF for flexion, extension, lateral bending, and axial torsion motion decreased with an increasing weight percentage of PVA in PVAH. When the results of the L1-L2, L2-L3, L3-L4, and L4-L5 segments were averaged, the ROMs of $20 \mathrm{wt} \%$ PVAH were lower than those of $3 \mathrm{wt} \%$ PVAH by $1.0 \%, 3.3 \%, 4.8 \%$, and $1.7 \%$ for flexion, extension, lateral bending, and axial torsion motions, respectively. The ROMs of the lumbar segments with $15 \mathrm{wt} \%$ and $20 \mathrm{wt} \%$ PVAH differed by only $0.45 \%$ and $0.86 \%$, respectively, compared with the ROMs and the NP. When the results of the L1-L2, L2-L3, L3-L4, and L4-L5 segments were averaged, the ROMs of $20 \mathrm{wt} \%$ PVAH were lower than those of $15 \mathrm{wt} \%$ PVAH by $0.5 \%, 1.6 \%, 2.0 \%$, and $1.0 \%$ for flexion, extension, lateral bending, and axial torsion motions, respectively (Figure 9). The FJFs of $20 \mathrm{wt} \%$ PVAH were lower than those of $3 \mathrm{wt} \%$ PVAH by $6.5 \%, 9.2 \%$, and $5.3 \%$ for extension, lateral bending, and axial torsion motions, respectively. The FJFs of the lumbar segments with $15 \mathrm{wt} \%$ and $20 \mathrm{wt} \%$ PVAH differed by only $0.8 \%$ and $1.4 \%$, respectively, compared with those of the NP. The FJFs of $20 \mathrm{wt} \%$ PVAH were lower than those of $15 \mathrm{wt} \%$ PVAH by $2.7 \%, 3.2 \%$, and $0.7 \%$ for extension, lateral bending, and axial torsion motions, respectively (Figure 10). Similarly, the maximum stress values generated in the IAF and OAF surrounding the NP (i.e., NP pressures) decreased with an increasing weight percentage of PVA in PVAH. In the IAF, the maximum stresses of $20 \mathrm{wt} \%$ PVAH (average values of the L1-L2 to L4-L5 segments) were lower than those of $3 \mathrm{wt} \%$ PVAH by $12.4 \%, 15.4 \%, 8.0 \%$, and $12.0 \%$ for flexion, extension, lateral bending, and axial torsion motions, respectively. Moreover, in the OAF, the maximum stresses of $20 \mathrm{wt} \%$ PVAH were lower than those of $3 \mathrm{wt} \%$ PVAH by $12.3 \%, 1.4 \%, 14.1 \%$, and $11.8 \%$ for flexion, extension, lateral bending, and axial torsion motions, respectively. The maximum stresses of the AF with $15 \mathrm{wt} \%$ and $20 \mathrm{wt} \%$ PVAH differed by only $2.1 \%$ and $3.2 \%$, respectively, compared with those of the NPs. In the AF, the maximum stress of $20 \mathrm{wt} \% \mathrm{PVAH}$ was 
lower than those of $15 \mathrm{wt} \%$ PVAH by $6.3 \%, 4.2 \%, 4.5 \%$, and $0.7 \%$ for flexion, extension, lateral bending, and axial torsion motions, respectively (Figure 11).
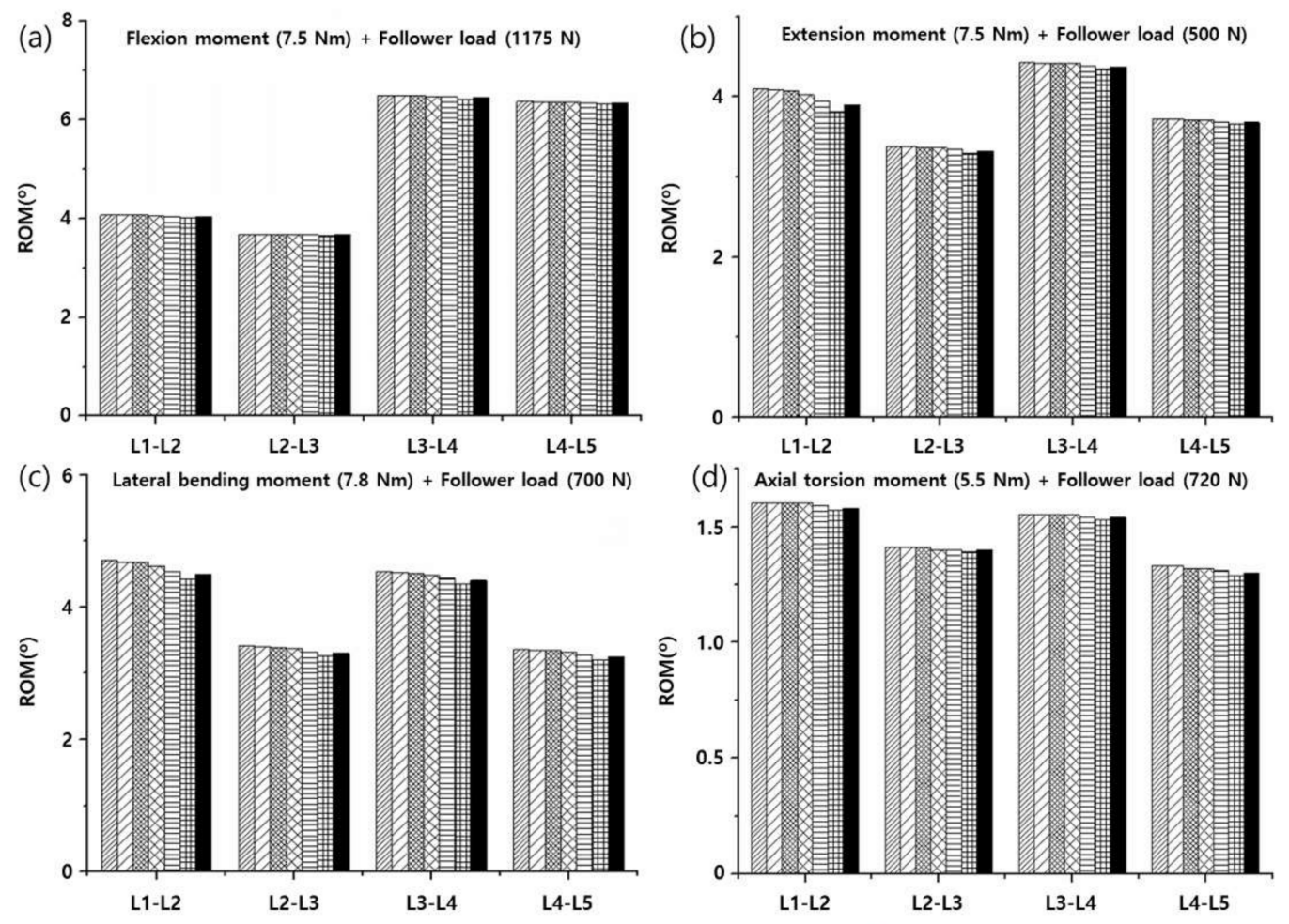

3 wt $\% \square$ wt\% 7 wt\% 10 wt $\%$

$15 w t \%$ 四冊 $20 w t \%$

Nucleus pulposus

Figure 9. Range of motions (ROMs) of the lumbar spine segments with PVAH to replace the NPs that were measured under a combination of (a) flexion moment $(7.5 \mathrm{~N} \cdot \mathrm{m})$ and follower load $(1175 \mathrm{~N}),(\mathbf{b})$ extension moment $(7.5 \mathrm{~N} \cdot \mathrm{m})$ and follower load $(500 \mathrm{~N})$, (c) lateral bending moment $(7.8 \mathrm{~N} \cdot \mathrm{m})$ and follower load $(700 \mathrm{~N})$, and $(\mathbf{d})$ axial rotation moment $(5.5 \mathrm{~N} \cdot \mathrm{m})$ and follower load $(720 \mathrm{~N})$.

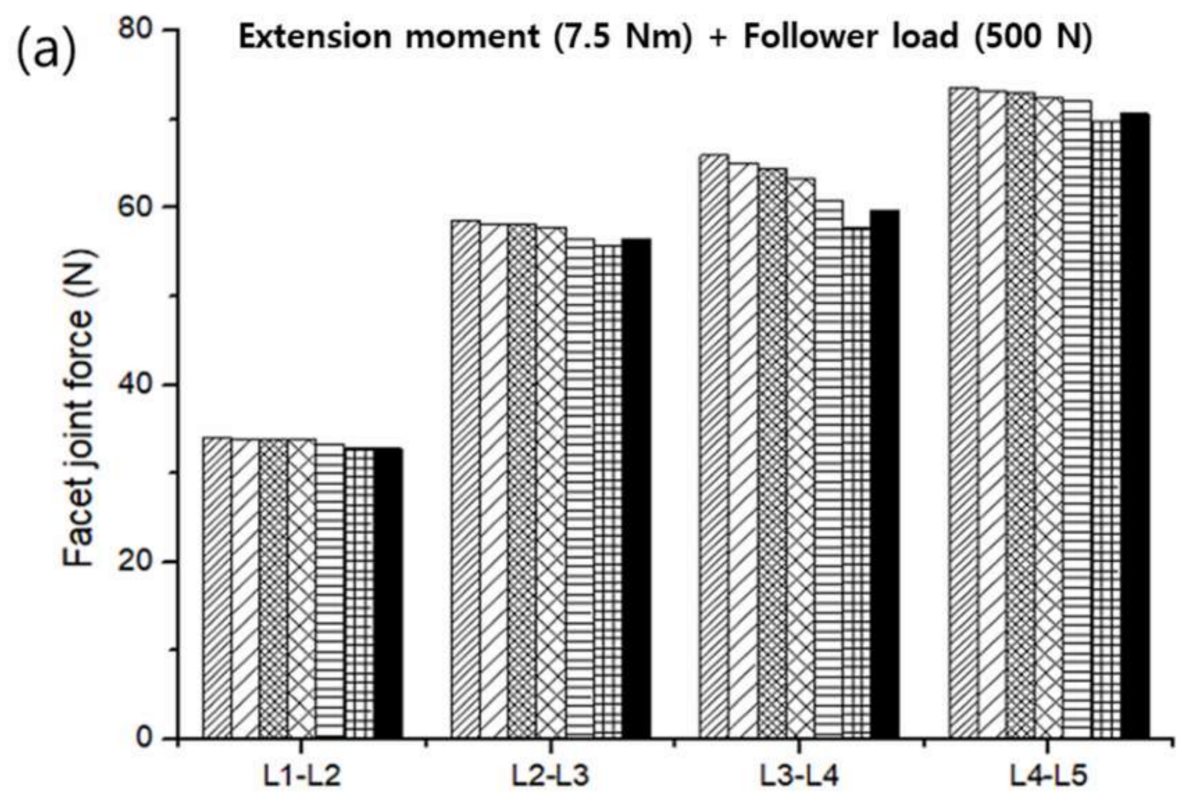

Figure 10. Cont. 

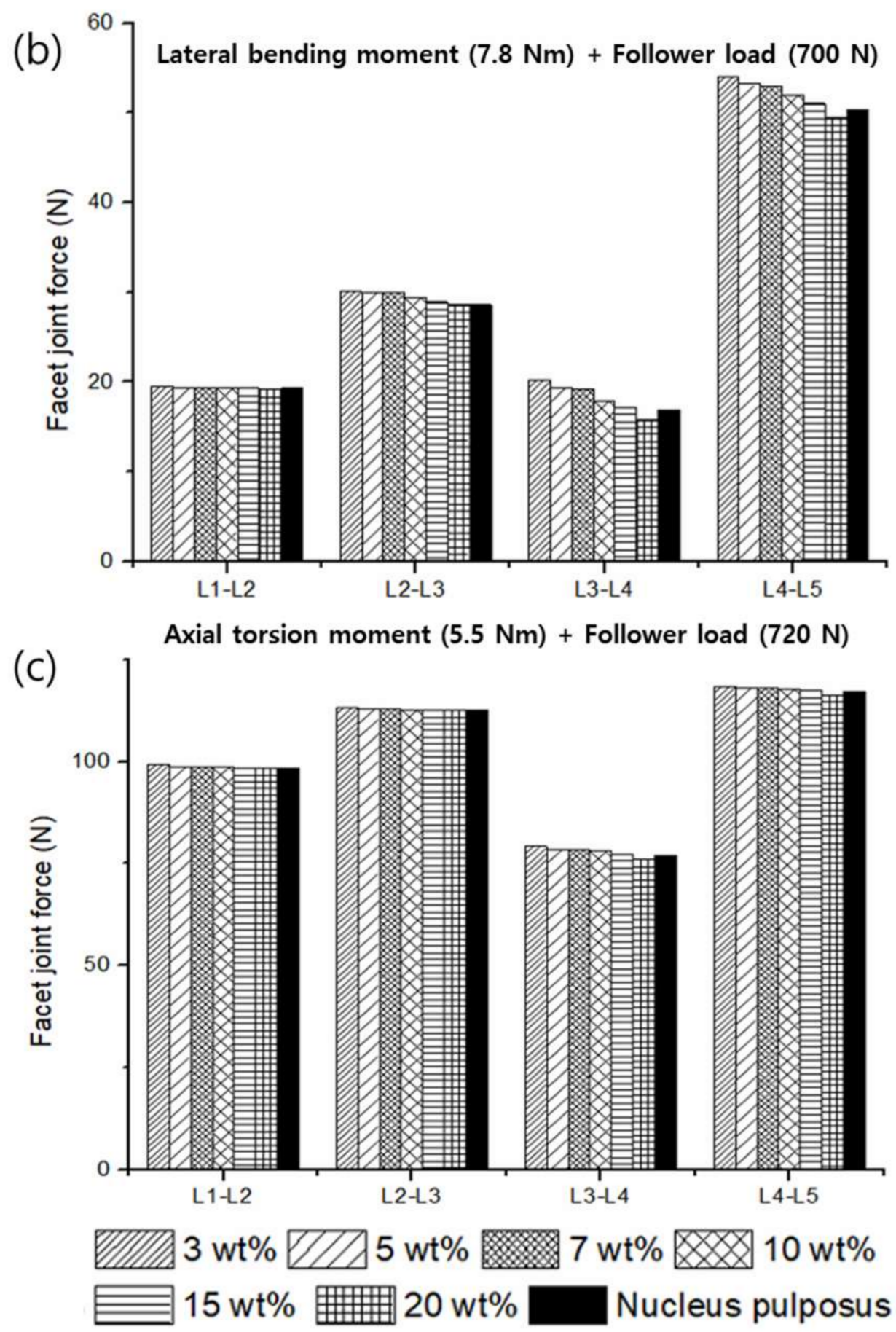

Figure 10. Facet joint forces (FJFs) of lumbar spine segments with PVAH to replace the NPs that were measured under a combination of (a) extension moment $(7.5 \mathrm{~N} \cdot \mathrm{m})$ and follower load $(500 \mathrm{~N})$, (b) lateral bending moment $(7.8 \mathrm{~N} \cdot \mathrm{m})$ and follower load $(700 \mathrm{~N})$, and $(\mathbf{c})$ axial rotation moment $(5.5 \mathrm{~N} \cdot \mathrm{m})$ and follower load $(720 \mathrm{~N})$. 

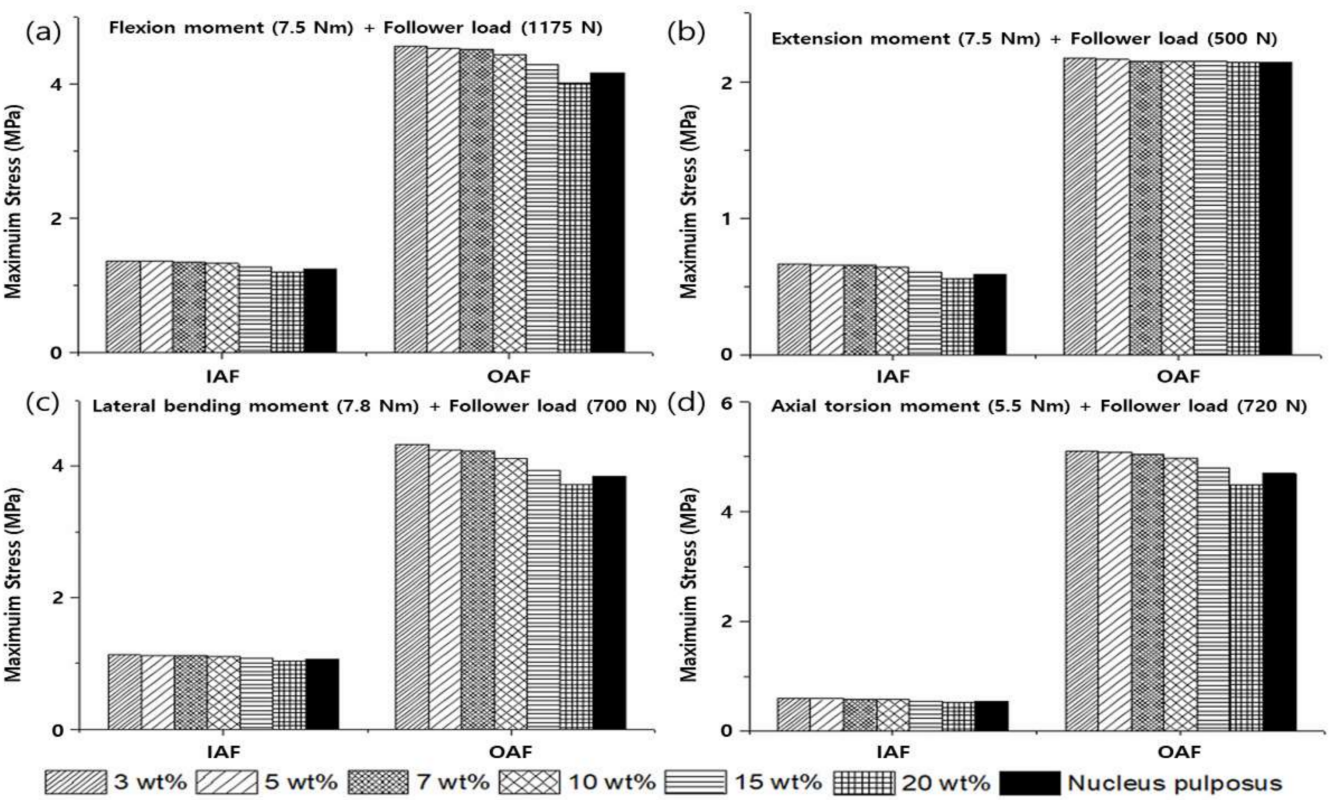

Figure 11. Maximum stresses for the inner annulus fibrosus (IAF) and the outer annulus fibrosus (OAF) of the lumbar spine segments with PVAH to replace the NPs that were measured under a combination of (a) flexion moment $(7.5 \mathrm{~N} \cdot \mathrm{m})$ and follower load $(1175 \mathrm{~N}),(\mathbf{b})$ extension moment $(7.5 \mathrm{~N} \cdot \mathrm{m})$ and follower load $(500 \mathrm{~N}),(\mathrm{c})$ lateral bending moment $(7.8 \mathrm{~N} \cdot \mathrm{m})$ and follower load $(700 \mathrm{~N})$, and $(\mathrm{d})$ axial rotation moment $(5.5 \mathrm{~N} \cdot \mathrm{m})$ and follower load $(720 \mathrm{~N})$ (each colored bar represents the average value of maximum stresses calculated in the L1-L2, L2-L3, L3-L4, and L4-L5 segments).

\section{Discussion}

This study aims to optimize the composition ratio of PVAH that can reflect the mechanical behavior of the NP and further reflect the range of motion (ROM) and facet joint forces (FJFs) of the L1-L2 to L4-L5 segments for flexion, extension, lateral bending, and axial torsion, although replaced by PVAH. To this end, six types of PVAH with different composition ratios of PVA and PBS were used to replace the NP, and their biphasic material properties were compared with those of the NPs. Furthermore, the ROMs and FJFs of the lumbar segments with PVAH were compared to those of the NP.

The finite element (FE) model of the lumbar spine developed in this study was verified by comparing the current results (ROMs, FJFs, NP pressures) with in vivo experimental data and finite element (FE) analysis results reported in the literature. Although the current results were reasonably consistent with the literature's findings, previous in vivo experimental results on the ROM for flexion motion exhibited a significant difference from the FE analysis results (Figure 6). This difference was presumably because the experimental measurements on the ROMs were taken with the subjects ( 11 male volunteers between the ages of 25 and 36 years) standing with their spine maximally flexed [56]. The applied flexion moment and follower load in in vivo experiments could be significantly different from those in the FE analysis. Regarding the FJFs, previous FE analysis results showed large variations depending on the FE model constructed by each researcher, mainly in the shape of the facet joint cartilage and friction conditions applied to the facet joint (Figure 7). These results suggest that the normal lumbar spine FE model proposed in this study reflects the physiological characteristics of the human lumbar spine, which makes it suitable for use in biomechanical analysis.

The stress-strain curves of PVAH obtained from unconfined compression experiments showed a toe region and a linear region and were identical to the compression behavior of various polymer materials (Figure 4) $[29,32,34,59]$. The Young's modulus $(E)$ obtained by curve-fitting unconfined compression experimental results using the Holmes-Mow model increased with an increasing weight percentage of PVA in PVAH. This is because the load required for compression increased with the increasing percentage of weight of 
PVA, owing to an increase in the solid matrix in PVAH. On the other hand, the permeability parameter $k_{0}$ decreased with an increasing weight percentage of PVA; this indicates that the low permeability $\left(k_{0}\right)$, caused by the small pore size from the high weight percentage of PVA required a long time to achieve steady-state equilibrium in the stress-relaxation behavior. This can be explained by the fact that the smaller pore size of PVAH with lower permeability $\left(k_{0}\right)$ provides higher fluid flow resistance, preventing fluid from flowing freely within the PVAH [60]. These results are consistent with those of previous studies [61]. The material properties of PVAH obtained by curve-fitting the experimental results were also compared with those of the NP in previous studies. As per the results, $E$ and $k_{0}$ of the NP are between those of $15 \mathrm{wt} \%$ and $20 \mathrm{wt} \% \mathrm{PVAH}$, respectively, indicating that $15 \mathrm{wt} \%$ and $20 \mathrm{wt} \%$ PVAH exhibit compressive properties similar to those of the NP.

In terms of dynamic motional analysis of the lumbar segments either with the NP or with PVAH, the ROMs, FJFs, and NP pressures were measured for flexion, extension, lateral bending, and axial torsions. These values of the lumbar segments with NP were similar to those with $15 \mathrm{wt} \%$ PVAH and $20 \mathrm{wt} \%$ PVAH. The maximum stresses of the IAF and the OAF tended to gradually decrease with an increasing weight percentage of PVA in PVAH for flexion, extension, lateral bending, and axial torsion because the pressures applied by the AF decreased with increasing $E$ of PVAH. This result also suggests that, as the $E$ of the PVAH decreases, the load applied to the AF increases, increasing the risk of causing lesions such as disc herniation due to AF tear. In this study, variations in the ROMs measured from the lumbar segments with different composition ratios of PVA and PBS in PVAH were smaller than variations in the $E$ measured from PVAH with different composition ratios of PVA and PBS. This is considered to be due to the role of the AF, a form that surrounds the NP, which absorbs the shock of the spine during exercise and evenly distributes the pressure applied to the spine to stabilize it [62-66].

\section{Conclusions}

Among the PVAHs used in our study, $15 \mathrm{wt} \%$ PVAH was more similar to the NP than $20 \mathrm{wt} \%$ PVAH in terms of the ROMs, while $20 \mathrm{wt} \%$ PVAH exhibited results more similar to the NP than $15 \mathrm{wt} \%$ PVAH in terms of the FJFs and the maximum stresses of the AF. Considering that the FJFs and AF maximum stresses could cause the risk of AF tears and/or the pain in the facet joints, and the difference between the ROMs with $15 \mathrm{wt} \%$ and $20 \mathrm{wt} \%$ was insignificant, it appears that $20 \mathrm{wt} \%$ PVAH is most suitable for replacing the NP. However, it is still possible that PVAH with a composition between $15 \mathrm{wt} \%$ and $20 \mathrm{wt} \%$ PVAH, such as $17 \mathrm{wt} \%$ PVAH may be closer to the properties of the human nucleus pulposus according to the current results. To evaluate PVAH as a functional substitute for NPs, further studies on material properties and fatigue and wear properties for PVAH with compositions between $15 \mathrm{wt} \%$ and $20 \mathrm{wt} \%$ are needed.

Author Contributions: Conceptualization, M.H. and S.P.; methodology, M.H.; investigation, M.H.; writing—original draft preparation, M.H.; writing—review and editing, S.P.; supervision, S.P.; project administration, S.P.; funding acquisition, S.P. All authors have read and agreed to the published version of the manuscript.

Funding: This research was funded by the National Research Foundation of Korea (NRF) grant funded by the Korean government (MSIP; No. NRF-2016R1A2B4012561, NRF-2021R1F1A1046890). and the APC was funded by the National Research Foundation of Korea (NRF) grant funded by the Korean government (MSIP; No. NRF-2016R1A2B4012561, NRF-2021R1F1A1046890).

Institutional Review Board Statement: Not applicable.

Informed Consent Statement: Not applicable.

Data Availability Statement: All relevant data are within the manuscript.

Conflicts of Interest: The authors declare no conflict of interest. 


\section{References}

1. Joshi, A.; Fussell, G.; Thomas, J.; Hsuan, A.; Lowman, A.; Karduna, A.; Vresilovic, E.; Marcolongo, M. Functional compressive mechanics of a PVA/PVP nucleus pulposus replacement. Biomaterials 2006, 27, 176-184. [CrossRef] [PubMed]

2. White, A.A., III; Panjabi, M.M. Clinical Biomechanics of the Spine; Lippincott Williams \& Wilkins: Philadelphia, PA, USA, 1990.

3. Bao, Q.B.; McCullen, G.M.; Higham, P.A.; Dumbleton, J.H.; Yuan, H.A. The artificial disc: Theory, design and materials. Biomaterials 1996, 17, 1157-1167. [CrossRef]

4. Iatridis, J.C.; Weidenbaum, M.; Setton, L.A.; Mow, V.C. Is the nucleus pulposus a solid or a fluid? Mechanical behaviors of the nucleus pulposus of the human intervertebral disc. Spine 1996, 21, 1174-1184. [CrossRef]

5. Nachemson, A. Some mechanical properties of the lumbar intervertebral disc. Bull. Hosp. Joint Dis. 1962, 23, 130-132. [PubMed]

6. Boyd, L.M.; Carter, A.J. Injectable biomaterials and vertebral endplate treatment for repair and regeneration of the intervertebral disc. Eur. Spine J. 2006, 15 (Suppl. 3), S414-S421. [CrossRef] [PubMed]

7. Di Martino, A.; Vaccaro, A.R.; Lee, J.Y.; Denaro, V.; Lim, M.R. Nucleus pulposus replacement: Basic science and indications for clinical use. Spine 2005, 30, S16-S22. [CrossRef] [PubMed]

8. Huang, R.C.; Wright, T.M.; Panjabi, M.M.; Lipman, J.D. Biomechanics of nonfusion implants. Orthop. Clin. N. Am. 2005, 36, 271-280. [CrossRef] [PubMed]

9. Joshi, A.; Mehta, S.; Vresilovic, E.; Karduna, A.; Marcolongo, M. Nucleus implant parameters significantly change the compressive stiffness of the human lumbar intervertebral disc. J. Biomech. Eng. 2005, 127, 536-540. [CrossRef]

10. Klara, P.M.; Ray, C.D. Artificial nucleus replacement: Clinical experience. Spine 2002, 27, 1374-1377. [CrossRef]

11. Larson, J.; Chadderon, R.; Georgescu, H.; Lee, D.; Hubert, M.; Werkmeister-Lewis, L.; Irrang, J.; Gilbertson, L.; Kang, J. Prevention of Intervertebral Disc Degeneration after Surgical Discectomy Using an Injectable Nucleus Pulposus Prosthesis. In Proceedings of the 52nd Annual Meeting of the Orthopaedic Research Society, Chicago, IL, USA, 19-22 March 2006.

12. Argoubi, M.; Shirazi-Adl, A. Poroelastic creep response analysis of a lumbar motion segment in compression. J. Biomech. 1996, 29, 1331-1339. [CrossRef]

13. Bao, Q.B.; Yuan, H.A. Prosthetic disc replacement: The future? Clin. Orthop. Relat. Res. 2002, 394, 139-145. [CrossRef] [PubMed]

14. Johannessen, W.; Elliott, D.M. Effects of degeneration on the biphasic material properties of human nucleus pulposus in confined compression. Spine 2005, 30, E724-E729. [CrossRef]

15. Lee, C.K.; Kim, Y.E.; Lee, C.S.; Hong, Y.M.; Jung, J.M.; Goel, V.K. Impact response of the intervertebral disc in a finite-element model. Spine 2000, 25, 2431-2439. [CrossRef] [PubMed]

16. Martinez, J.B.; Oloyede, V.O.; Broom, N.D. Biomechanics of load-bearing of the intervertebral disc: An experimental and finite element model. Med. Eng. Phys. 1997, 19, 145-156. [CrossRef]

17. Iatridis, J.C.; Setton, L.A.; Weidenbaum, M.; Mow, V.C. Alterations in the mechanical behavior of the human lumbar nucleus pulposus with degeneration and aging. J. Orthop. Res. 1997, 15, 318-322. [CrossRef] [PubMed]

18. Iatridis, J.C.; Setton, L.A.; Weidenbaum, M.; Mow, V.C. The viscoelastic behavior of the non-degenerate human lumbar nucleus pulposus in shear. J. Biomech. 1997, 30, 1005-1013. [CrossRef]

19. Cortes, D.H.; Jacobs, N.T.; DeLucca, J.F.; Elliott, D.M. Elastic, permeability and swelling properties of human intervertebral disc tissues: A benchmark for tissue engineering. J. Biomech. 2014, 47, 2088-2094. [CrossRef]

20. Jacobs, N.T.; Cortes, D.H.; Peloquin, J.M.; Vresilovic, E.J.; Elliott, D.M. Validation and application of an intervertebral disc finite element model utilizing independently constructed tissue-level constitutive formulations that are nonlinear, anisotropic, and time-dependent. J. Biomech. 2014, 47, 2540-2546. [CrossRef]

21. Nerurkar, N.L.; Elliott, D.M.; Mauck, R.L. Mechanical design criteria for intervertebral disc tissue engineering. J. Biomech. 2010, 43, 1017-1030. [CrossRef]

22. del Palomar, A.P.; Calvo, B.; Doblare, M. An accurate finite element model of the cervical spine under quasi-static loading. J. Biomech. 2008, 41, 523-531. [CrossRef]

23. Malandrino, A.; Planell, J.A.; Lacroix, D. Statistical factorial analysis on the poroelastic material properties sensitivity of the lumbar intervertebral disc under compression, flexion and axial rotation. J. Biomech. 2009, 42, 2780-2788. [CrossRef] [PubMed]

24. Schroeder, Y.; Huyghe, J.M.; van Donkelaar, C.C.; Ito, K. A biochemical/biophysical 3D FE intervertebral disc model. Biomech Model. Mechanobiol. 2010, 9, 641-650. [CrossRef] [PubMed]

25. Stokes, I.A.; Laible, J.P.; Gardner-Morse, M.G.; Costi, J.J.; Iatridis, J.C. Refinement of elastic, poroelastic, and osmotic tissue properties of intervertebral disks to analyze behavior in compression. Ann. Biomed. Eng. 2011, 39, 122-131. [CrossRef] [PubMed]

26. Chu, K.C.; Rutt, B.K. Polyvinyl alcohol cryogel: An ideal phantom material for MR studies of arterial flow and elasticity. Magn Reson. Med. 1997, 37, 314-319. [CrossRef] [PubMed]

27. Jiang, H.; Campbell, G.; Boughner, D.; Wan, W.K.; Quantz, M. Design and manufacture of a polyvinyl alcohol (PVA) cryogel tri-leaflet heart valve prosthesis. Med. Eng. Phys. 2004, 26, 269-277. [CrossRef]

28. Vijayasekaran, S.; Fitton, J.H.; Hicks, C.R.; Chirila, T.V.; Crawford, G.J.; Constable, I.J. Cell viability and inflammatory response in hydrogel sponges implanted in the rabbit cornea. Biomaterials 1998, 19, 2255-2267. [CrossRef]

29. Stammen, J.A.; Williams, S.; Ku, D.N.; Guldberg, R.E. Mechanical properties of a novel PVA hydrogel in shear and unconfined compression. Biomaterials 2001, 22, 799-806. [CrossRef]

30. Allen, M.J.; Schoonmaker, J.E.; Bauer, T.W.; Williams, P.F.; Higham, P.A.; Yuan, H.A. Preclinical evaluation of a poly (vinyl alcohol) hydrogel implant as a replacement for the nucleus pulposus. Spine 2004, 29, 515-523. [CrossRef] 
31. Thomas, J.; Lowman, A.; Marcolongo, M. Novel associated hydrogels for nucleus pulposus replacement. J. Biomed. Mater. Res. A 2003, 67, 1329-1337. [CrossRef]

32. Sasson, A.; Patchornik, S.; Eliasy, R.; Robinson, D.; Haj-Ali, R. Hyperelastic mechanical behavior of chitosan hydrogels for nucleus pulposus replacement-experimental testing and constitutive modeling. J. Mech. Behav. Biomed. Mater. 2012, 8, 143-153. [CrossRef]

33. Cloyd, J.M.; Malhotra, N.R.; Weng, L.; Chen, W.; Mauck, R.L.; Elliott, D.M. Material properties in unconfined compression of human nucleus pulposus, injectable hyaluronic acid-based hydrogels and tissue engineering scaffolds. Eur. Spine J. 2007, 16, 1892-1898. [CrossRef] [PubMed]

34. Kobayashi, M.; Toguchida, J.; Oka, M. Development of an artificial meniscus using polyvinyl alcohol-hydrogel for early return to, and continuance of, athletic life in sportspersons with severe meniscus injury. I: Mechanical evaluation. Knee 2003, 10, 47-51. [CrossRef]

35. Nakashima, K.; Sawae, Y.; Murakami, T. Study on wear reduction mechanisms of artificial cartilage by synergistic protein boundary film formation. JSME Int. J. Ser. C Mech. Syst. Mach. Elem. Manuf. 2005, 48, 555-561. [CrossRef]

36. Cortes, D.H.; Elliott, D.M. Extra-fibrillar matrix mechanics of annulus fibrosus in tension and compression. Biomech. Model. Mechanobiol. 2012, 11, 781-790. [CrossRef]

37. Garcia, J.J.; Cortes, D.H. A nonlinear biphasic viscohyperelastic model for articular cartilage. J. Biomech. 2006, 39, 2991-2998 [CrossRef]

38. Holmes, M.H.; Mow, V.C. The nonlinear characteristics of soft gels and hydrated connective tissues in ultrafiltration. J. Biomech 1990, 23, 1145-1156. [CrossRef]

39. Iatridis, J.C.; Setton, L.A.; Foster, R.J.; Rawlins, B.A.; Weidenbaum, M.; Mow, V.C. Degeneration affects the anisotropic and nonlinear behaviors of human anulus fibrosus in compression. J. Biomech. 1998, 31, 535-544. [CrossRef]

40. Masharawi, Y.; Rothschild, B.; Dar, G.; Peleg, S.; Robinson, D.; Been, E.; Hershkovitz, I. Facet orientation in the thoracolumbar spine-Three-dimensional anatomic and biomechanical analysis. Spine 2004, 29, 1755-1763. [CrossRef]

41. Sharma, M.; Langrana, N.A.; Rodriguez, J. Role of ligaments and facets in lumbar spinal stability. Spine 1995, 20, 887-900. [CrossRef]

42. Senegas, J. Mechanical supplementation by non-rigid fixation in degenerative intervertebral lumbar segments: The Wallis system. Eur. Spine J. 2002, 11, S164-S169. [CrossRef]

43. Sengupta, D.K. Dynamic stabilization devices in the treatment of low back pain. Neurol. India 2005, 53, 466-474. [CrossRef] [PubMed]

44. Yang, B.; O'Connell, G.D. Effect of collagen fibre orientation on intervertebral disc torsion mechanics. Biomech. Model. Mechanobiol. 2017, 16, 2005-2015. [CrossRef] [PubMed]

45. He, L.; Zhang, M.C.; Feng, F.; Pang, M.; Xie, P.G.; Chen, R.Q.; Rong, L.M. Stress distribution over lumbosacral vertebrae and axial transsacral rod after axial lumbar interbody fusion (AxiaLIF): Finite element analysis. Int. J. Clin. Exp. Med. 2016, 9, 13372-13383.

46. Kim, Y.; Kim, T.W. Finite element analysis of the effects of pedicle screw fixation nut loosening on lumbar interbody fusion based on the elasto-plateau plasticity of bone characteristics. Spine 2010, 35, 599-606. [CrossRef] [PubMed]

47. Zheng, J.; Yang, Y.H.; Lou, S.L.; Zhang, D.S.; Liao, S.H. Construction and validation of a three-dimensional finite element model of degenerative scoliosis. J. Orthop. Surg. Res. 2015, 10, 189. [CrossRef] [PubMed]

48. Natarajan, R.N.; Chen, B.H.; An, H.S.; Andersson, G.B. Anterior cervical fusion: A finite element model study on motion segment stability including the effect of osteoporosis. Spine 2000, 25, 955-961. [CrossRef] [PubMed]

49. Goel, V.K.; Monroe, B.T.; Gilbertson, L.G.; Brinckmann, P.; Nat, R. Interlaminar shear stresses and laminae separation in a disc-Finite-element analysis of the L3-L4 motion segment subjected to axial compressive loads. Spine 1995, 20, 689-698. [CrossRef]

50. Shiraziadl, A.; Ahmed, A.M.; Shrivastava, S.C. Mechanical response of a lumbar motion segment in axial torque alone and combined with compression. Spine 1986, 11, 914-927. [CrossRef]

51. Zander, T.; Rohlmann, A.; Calisse, J.; Bergmann, G. Estimation of muscle forces in the lumbar spine during upper-body inclination Clin. Biomech. 2001, 16, S73-S80. [CrossRef]

52. Rohlmann, A.; Zander, T.; Rao, M.; Bergmann, G. Realistic loading conditions for upper body bending. J. Biomech. 2009, 42, 884-890. [CrossRef]

53. Dreischarf, M.; Rohlmann, A.; Bergmann, G.; Zander, T. Optimised in vitro applicable loads for the simulation of lateral bending in the lumbar spine. Med. Eng. Phys. 2012, 34, 777-780. [CrossRef] [PubMed]

54. Dreischarf, M.; Rohlmann, A.; Bergmann, G.; Zander, T. Optimised loads for the simulation of axial rotation in the lumbar spine. J. Biomech. 2011, 44, 2323-2327. [CrossRef] [PubMed]

55. Dreischarf, M.; Zander, T.; Shirazi-Adl, A.; Puttlitz, C.M.; Adam, C.J.; Chen, C.S.; Goel, V.K.; Kiapour, A.; Kim, Y.H.; Labus, K.M.; et al. Comparison of eight published static finite element models of the intact lumbar spine: Predictive power of models improves when combined together. J. Biomech. 2014, 47, 1757-1766. [CrossRef] [PubMed]

56. Pearcy, M.; Portek, I.; Shepherd, J. Three-dimensional x-ray analysis of normal movement in the lumbar spine. Spine 1984, 9 , 294-297. [CrossRef]

57. Pearcy, M.J. Stereo radiography of lumbar spine motion. Acta Orthop. Scand. Suppl. 1985, 212, 1-45. [CrossRef]

58. Pearcy, M.J.; Tibrewal, S.B. Axial rotation and lateral bending in the normal lumbar spine measured by three-dimensional radiography. Spine 1984, 9, 582-587. [CrossRef] 
59. Anseth, K.S.; Bowman, C.N.; Brannon-Peppas, L. Mechanical properties of hydrogels and their experimental determination. Biomaterials 1996, 17, 1647-1657. [CrossRef]

60. Lai, W.M.; Mow, V.C.; Roth, V. Effects of nonlinear strain-dependent permeability and rate of compression on the stress behavior of articular cartilage. J. Biomech. Eng. 1981, 103, 61-66. [CrossRef]

61. Gao, X.; Kusmierczyk, P.; Shi, Z.; Liu, C.; Yang, G.; Sevostianov, I.; Silberschmidt, V.V. Through-thickness stress relaxation in bacterial cellulose hydrogel. J. Mech. Behav. Biomed. Mater. 2016, 59, 90-98. [CrossRef]

62. Adams, P.; Eyre, D.R.; Muir, H. Biochemical aspects of development and ageing of human lumbar intervertebral discs. Rheumatol. Rehabil. 1977, 16, 22-29. [CrossRef]

63. Cassidy, J.J.; Hiltner, A.; Baer, E. Hierarchical structure of the intervertebral disc. Connect. Tissue Res. 1989, 23, 75-88. [CrossRef] [PubMed]

64. Hsu, E.W.; Setton, L.A. Diffusion tensor microscopy of the intervertebral disc anulus fibrosus. Magn. Reson. Med. 1999, 41, 992-999. [CrossRef]

65. Yu, J.; Fairbank, J.C.; Roberts, S.; Urban, J.P. The elastic fiber network of the anulus fibrosus of the normal and scoliotic human intervertebral disc. Spine 2005, 30, 1815-1820. [CrossRef] [PubMed]

66. Yu, J.; Tirlapur, U.; Fairbank, J.; Handford, P.; Roberts, S.; Winlove, C.P.; Cui, Z.; Urban, J. Microfibrils, elastin fibres and collagen fibres in the human intervertebral disc and bovine tail disc. J. Anat. 2007, 210, 460-471. [CrossRef] 